\title{
The 2013 Genetics Society of America Elizabeth W. Jones Award for Excellence in Education A. Malcolm Campbell
}

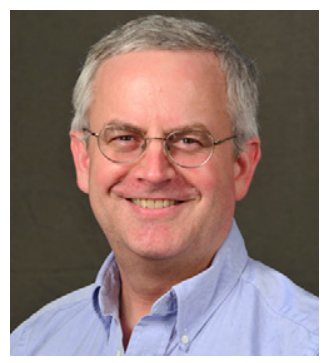

Imagine a college biology classroom filled with students of diverse ethnic and socioeconomic backgrounds. The students expect to learn the state of current scientific knowledge, but they are surprised that they will be given a chance to experience firsthand where science is going. The students are doing real genomics and synthetic biology research as part of their normal course work. Now imagine the cost of this work is very inexpensive and generates publishable data.

7 fes OU just heard the vision of A. Malcolm Campbell, Professor of Biology at Davidson College (Davidson, NC) and the 2013 recipient of the Elizabeth W. Jones Award for Excellence in Education. The Genetics Society of America (GSA) is very pleased to honor the sustained and significant contributions to biology education, particularly in the area of genomics education, made by Dr. Campbell over the last two decades.

Malcolm made his vision of hands-on cutting-edge research activities in the undergraduate curriculum a reality not only at his home institution, but also by bringing together faculty members from diverse institutions to learn and implement new techniques in molecular genetics. He cites a talk on the invention of microarrays at the 1998 American Society for Cell Biology (ASCB) meeting by Pat Brown, from Stanford University (Stanford, CA), as inspirational. Malcolm recalls, "When Brown said the cost of a microarray was $\$ 5.00$, I looked at my colleague Mary Lee Ledbetter (of the College of the Holy Cross, Worcester, MA) and remarked that even primarily undergraduate institutions (PUIs) could afford microarrays. I said, 'We could start a consortium to buy microarrays and distribute them at cost to faculty members teaching undergraduates." Pat Brown, and later Lee Hood, donated the first sets of microarrays to get the consortium, cleverly called GCAT, the Genome Consortium for Active Teaching, up and running (Campbell et al. 2006, 2007).

Copyright (C) 2013 by the Genetics Society of America doi: 10.1534/genetics.113.150698
When asked about the obstacles the consortium faced, Malcolm replied, "The first and most glaring obstacle was that none of the professors involved had ever seen a DNA microarray before nor had we been trained in the data analysis process. However, professors routinely model lifelong learning for their students and this group was determined to develop undergraduate-friendly protocols for a process they still had not learned themselves." And so they did. Faculty members from three PUIs pooled their talents to write a successful grant to the National Science Foundation (NSF) to purchase a microarray scanner that Malcolm ran at Davidson. This consortial approach worked later as PUI faculty wrote grants to the Howard Hughes Medical Institute (HHMI) that included funding to continue and extend GCAT workshops. Another collaboration led to the development of open-source tools for microarray data analysis that could be used not only by workshop participants but also by anyone analyzing data generated by microarrays. Malcolm's collaborator at Davidson, Professor of Mathematics Laurie Heyer, and her students, developed open-source JAVA-based software (MAGIC Tool) by which the microarray-generated data could be analyzed (Heyer et al. 2005).

Says Heyer:

We have come to call our collaboration a partnership because we work so closely on so many things, and because we both do a lot of give and take to make our joint efforts the best they can be.... Malcolm has a vision for ways to integrate math into biology, and I have a passion for implementing the vision. He has taught me so much about how to write and speak about math for a biology audience, and is my best critic, helping me aim at the right level, with the right motivation of using math to understand biology. When working on textbook projects, Malcolm finds these great stories in the primary literature, and boils them down for students. Then I have come along behind and found connections for mathematics, so the math is aimed specifically at the biological story. There is no gratuitous math in the work we have done together!..... My personal memory about Malcolm's teaching style is that he is the king of analogies. He can come up with the wildest 
connections, out of the blue, with a moment's notice. . .You'll be talking about how this protein binds to that one and makes a certain process start in the cell, and all of a sudden he will say something like 'Have you ever driven a 4-wheel drive vehicle?' and you wonder what on earth that has to do with proteins, but then he lays out this great explanation that ties the concepts together, and suddenly you have a much better understanding of biology.

As genomics technology evolved, Malcolm has seen to it that GCAT also evolved. GCAT-SEEK fosters incorporation of massively parallel sequencing technologies in undergraduate curricula. Vincent Buonaccorsi, Associate Professor of Biology at Juniata College (Huntington, PA), who leads this portion of GCAT, has praise for Malcolm's vision, "Malcolm's work with GCAT made the seemingly impossible, possible for faculty teaching at small liberal arts colleges. He has inspired and emboldened existing faculty to reach higher in their teaching and research efforts and has benefited thousands of students in the process. Personally, Malcolm has been a tremendous source of encouragement and wisdom as we take steps to extend his good work with microarrays into the realm of next-generation sequencing."

Malcolm's current area of work, GCAT-SynBio, uses another unique consortial approach to bring synthetic biology into biology curricula. In this case, pairs of faculty, one in biology and one outside of biology, are invited to HHMI and NSF-sponsored workshops to learn to use the GCAT-alog of standardized DNA parts to build DNA-based parts, devices, and systems.

NSF Program Director, Sally O'Connor, says that "Malcolm's accomplishments are truly amazing. His efforts have resulted in a large number of undergraduate students experiencing the thrill of research right in their own classrooms and labs. When genomics technology changed, Malcolm re-designed the curriculum to respond to the newer technology. He has unselfishly devoted his time and effort to training faculty from predominantly undergraduate institutions, including those that serve many students from underrepresented groups."

Malcolm's work with his students in synthetic biology has led to nine publications since 2007, including two (Haynes et al. 2008; Baumgardner et al. 2009) chosen as Outstanding Publications two years in a row by the Journal of Biological Engineering. GCAT-SynBio participants add to the GCAT-alog of parts as they develop them and make them available to others. To facilitate equal distribution pressure, once someone sends a part to a colleague, the provider goes to the bottom of the list for future sharing. Don't we all wish that University committee service worked this way?

In its 13-year history, GCAT has taught over 500 college professors in workshops on microarrays, synthetic biology, and genome sequencing. It was chosen as a model laboratory experience for undergraduates by the National Research Council report called BIO2010 (Committee on Undergraduate Biology Education to Prepare Research Scientists for the 21st Century, National Research Council 2003). The faculty members, in turn, teach over 50,000 undergraduates per year. Valerie Watt, Director of Human Biology at the University of Toronto, relates the review of one of her students, "it was really cool to be exposed to modern lab techniques and get direct insight into the scientific research process." Faculty participants are similarly effusive in their praise for Malcolm's work and leadership of GCAT. Edison Fowlks, Professor of Biology and Director of the Biotechnology laboratory at Hampton University (Hampton, VA) writes: "Malcolm is on the forefront of the movement to transform undergraduate biology. He is a strong proponent for creating teaching environments to promote active learning and engaging students in the learning process. Indeed, he an outstanding teacher and scholar." Anne Rosenwald, Assistant Professor at Georgetown University (Washington, DC), notes, "Malcolm has been a leader in bringing authentic research experiences to undergraduate students, not only at Davidson, but through his work in GCAT." And Maria Santisteban, Assistant Professor, University of North Carolina at Pembroke, provides effusive praise for Malcolm's impact on her career and on her ability to reach her own students,

I have the highest respect and admiration for Malcolm, not only his dedication, passion, and vision for undergraduate education but his tireless nature to work hard and innovate. At a microarray workshop, I remember Malcolm spent most of the nights working on improving the website, uploading images from the workshop, and during the day he would not waste a second. Malcolm is one of the smartest people I have ever known; he's clever, fast, incisive and tons of fun! He has had a very positive impact on my career.

The collaborative consortial approach used by Malcolm in GCAT, while perhaps not unique, is noteworthy. Sarah (Sally) Elgin, Viktor Hamburger Professor of Biology at Washington University in St. Louis, notes, "Malcolm has done a brilliant job of continuing to bring to the forefront the idea of biologists working together within a consortium to improve biology education and to create new knowledge through research. He has dedicated countless hours to providing a core for GCAT, not only providing professional development experiences for many faculty, but showing us all the benefits of collaborative efforts." Consuelo Alvarez, Assistant Professor of Biology, Longwood University (Farmville, VA) has heart-felt words of support for Malcolm's efforts to support and engage with faculty and students from diverse backgrounds, "Malcolm has been a great mentor and peer for me. He is the most generous, thoughtful, and fun person with whom to work. He creates bridges to help and support anyone who is an educator. He sees different cultures as strengths from which we can grow together. I am honored to know him and to call him my friend."

What is striking about the work of Malcolm is that it is imbued with a sense of wonder and excitement coupled with a generosity that is inspiring. When asked about how he got his start in biology, Malcolm reports: "As a kid, I loved playing with critters of various sorts and I was inspired to become a marine biologist by watching films made by Jacques Cousteau. Though 
marine biology became less appealing after a summer counting nematodes in core samples for $40 \mathrm{hr}$ per week, I got turned on to molecular genetics during a summer research stint at Johns Hopkins looking at isozymes in a geographic gradient in fish populations." Malcolm went on to earn his Ph.D. at Johns Hopkins University (Baltimore, MD) with Douglas Fambrough. He returned to his undergraduate alma mater, Davidson College, in 1994 as an assistant professor.

When asked about his strong commitment to sharing his classroom experiences with other faculty and in forming consortia to spread the wealth, Malcolm is characteristically thoughtful yet playful, stating that "both of my parents are ministers, so perhaps I am an evangelical biologist; I love opening up the world of biology to as many people as possible." And this he has most certainly done. Malcolm is generous in citing the mentorship and opportunities he received, starting with tutoring the "toughest guy in my $5^{\text {th }}$ grade class in math and succeeding," and later earning a Teacher-Scholar Postdoctoral Fellowship from the Pew (now Midstates) Consortium through which Malcolm did genetics research with Ursula Goodenough at Washington University and then taught with Jan Serie at Macalester College (St. Paul, MN). With characteristic modesty, Malcolm says of this time, "The Pew Fellowship was a huge advantage for me because I learned so much about teaching and education. Both Ursula and Jan were truly gifted and inspirational."

Malcolm has not limited his work on improving biology education to active learning strategies in the area of genomics. He was a long-time member of the education committee of the ASCB where he helped establish a journal dedicated to biology education. As a result, he and Sarah (Sally) Elgin were cofounding editors of CBE Life Sciences Education. Elgin has this to say about their work on this project:

Malcolm's role was absolutely essential to launching $C B E$ Life Sciences Education, it couldn't have been done by any one person. We wanted a journal that would acknowledge the challenges at all levels of biology education, and one that would be written by and for biologists, for us. We had a vision of bringing together all biology educators while honoring the differences within the subdiscplines of biology. Working together with Malcolm was a great pleasure.

Elgin and Campbell needed to determine how educational articles would be reviewed and then they "beat the bushes" for submissions to the journal. Of course, it has been very successful. The ASCB honored both Sarah (Sally) Elgin and Malcolm in 2006 with the Bruce Alberts Education Award for their efforts in launching the journal, among other things. The GSA is pleased to be partnering with $C B E$ Life Sciences Education beginning in 2013.

But Malcolm has not been resting on his laurels. Instead, he has written the first true genomics textbook, in its second edition, with his collaborator Laurie Heyer, Discovering Genomics, Proteomics, and Bioinformatics (Campbell and Heyer 2007), and just coauthored an introductory biology text, with Heyer and ecologist Chris Paradise, that will be in electronic format. He has worked on revisions to the high school advanced placement (AP) curriculum, and, oh yes, he still teaches full time at Davidson and makes materials available to other instructors on his web site and through numerous invited presentations and workshops. Malcolm was one of 12 members of the phase I redesign commission for AP biology that reduced the content and focused on the big ideas of biology. His work with AP biology redesign inspired him to write the new introductory textbook de novo.

Barbara Lom, Associate Professor and Chair, Biology, at Davidson, lauds Malcolm's commitment to education, near and far. She says, "While he works tirelessly with bold ambitions to revolutionize improvements in undergraduate biology education worldwide, at the same time, his first priority is providing each of his Davidson students with thoughtful feedback and individualized coaching to be their best."

In all that he does, Malcolm's generosity of spirit, love of biology, and love of other people shines through. He says, "I'm grateful to the Davidson administration for encouraging me to explore and, really, I can't believe they pay me for this! I get paid to do what I love." Todd Eckdahl, Professor and Chair of Biology at Missouri Western State University (St. Joseph, MO), a GCAT participant, sums it up:

As a talented and passionate educator, Malcolm Campbell has served as a role model for hundreds of biology professors seeking to engage their undergraduate students in the practice of cutting edge genomics and synthetic biology. His leadership in GCAT has made a positive impact on the education of tens of thousands of students throughout the country and beyond.

Congratulations, Malcolm Campbell!

\section{Literature Cited}

Baumgardner, J., K. Acker, O. Adefuye, S. T. Crowley, W. DeLoache et al., 2009 Solving a Hamiltonian path problem with a bacterial computer. J. Biol. Eng. 3:11.

Campbell, A. M., and L. J. Heyer, 2007 Discovering Genomics, Proteomics, and Bioinformatics Ed. 2. Cold Spring Harbor Laboratory Press and Benjamin Cummings, San Francisco, CA.

Campbell, A. M., T. T. Eckdahl, E. Fowlks, L. J. Heyer, L. L. Mays Hoopes et al., 2006 Genome Consortium for Active Teaching (GCAT). Science 311: 1103-1104.

Campbell, A. M., M. L. Ledbetter, L. L. Hoopes, T. T. Eckdahl, L. J. Heyer et al., 2007 Genome Consortium for Active Teaching: Meeting the goals of BIO2010. CBE Life Sci. Educ. 6:109-118.

Committee on Undergraduate Biology Education to Prepare Research Scientists for the 21st Century, National Research Council, 2003 "Front Matter." BIO2010: Transforming Undergraduate Education for Future Research Biologists. National Academies Press, Washington, DC.

Haynes, K. A., M. L. Broderick, A. D. Brown, T. L. Butner, J. O. Dickson et al., 2008 Engineering bacteria to solve the Burnt Pancake Problem. J. Biol. Eng. 2(8): 1-12.

Heyer, L., D. Z. Moskowitz, J. A. Abele, P. 1. Karnik, D. Choi et al., 2005 MAGIC Tool: Integrated microarray data analysis. Bioinform. Appl. 21(9): 2114-2115.

Elizabeth Ann De Stasio 